\title{
Two Interviews with Leslie Marmon Silko
}

By

Per Seyersted

University of Oslo

\section{1: Laguna, New Mexico, January 7, 1976}

Per Seyersted: You went to school in Albuquerque, didn't you?

Leslie Marmon Silko: Right. Four years I went here to the day school, just across the road here, and then I finished up school in Albuquerque.

$P S$ : Did you feel it as difficult to be outside the Laguna environment?

LMS: Well, I've never encountered any kinds of vicious racial confrontations. I suppose it was more a feeling very strange, everything about Albuquerque and the kids I was going to school with, and that whole setting was very strange, kind of alien, and I moved through it as best I could, which I think most of the people from the Pueblos and from the reservations do even now. We move through the city, we taik with the people, but there's an extreme amount of tension that one feels and it can only be described as strangeness. We were fortunate that our parents sent us to small schools, not to public schools, and at the Catholic schools of course they were very strict about any sort of teasing and things like that, so we were pretty secure there. But I can remember one fall after hunting season we'd all done well and we got deer and my dad's aunt over at Paguate dried the meat and made jerky out of it. I can remember in the eighth grade taking my lunch to school. I hated to get up in the morning to make my lunch and I would take a large handful of dry meat and stuff it into my paper lunchbag and then maybe put in a candy bar and an orange and that was my lunch. This was a girls' school; my classmates on either side of me kind of jumped up and kind of scooted back, and they said, "What's that? It looks terrible," and I said, "Will you want to taste 
some of it?" and they said, "No!" Fortunately I was old enough,, or maybe secure enough, not to feel ... or at least I wasn't conscious of feeling ashamed of having brought that. It also had to do with my attitude which was I was always ... I made the most of being different, and so I can remember laughing at them and telling them, you know, actually taking a piece of meat - and these are eighth grade, ninth grade girls - and either sort of shoving a piece of meat, of this dry meat toward them and watching them jump as if it were a snake or something. I mean, I took that attitude that they were the ones that were silly and not: myself that thus ... So it was that $I$ was aware of encountering, but it was that ltind of conflict more than it was any kind of brutal or vicious kind of ... it was more subtle.

PS: Compared to many other people who are not "in the mainstream of the American life," wouldn't you say that you have had a great security, a great strength in the fact that you are solidly based in your own culture, and that as you said, you feel the others were strangers?

$L M S$ : Yeah, just maybe I think of it more in terms of even just the place. A lot of these hills and mesas I showed you this morning: there's a sense of familiarity almost like certain places being a parent or relative, in other words, being related to the land in a familiar way, and there's a kind of security there which I always feel. You know, when I was going to the university, during the school term I lived in Albuquerque, but as soon as we would leave Albuquerque and gradually drive back into this area, a feeling comes just of being in a place. Not to mention that I have always felt ... when the people here like the sacristan that we met up at the church ... you know, I remember Joe from the time I was so little that I wasn't in school, and he remembers me, and there's also, of course, then, that kind of security. There again I ... when that security is tied in with people ... of course, people pass away, eventually ... that's the beauty of the land, you know, that these things ... and this is why it is important to me: my father tells me stories that his father told him about certain places, and it is as if when one goes back to these places that all of those past things that happened in that place, in a sense, their presence is still there, and so you don't lose it, even though human beings may pass away and old age comes and so forth. And there's a sense of having even with one's relatives back through the years ... that somehow they are still there, they are still a presence. So, yes, then you have this, and 
it never fails. I was afraid when I came back from Alaska that maybe somehow it wouldn't feel that way anymore. Two years in Alaska was the longest I have ever been away from this part of the country. It was magical. I came back and maybe I felt it more strongly than I ever had.

$P S$ : You have chosen to write about a number of male characters, haven't you?

$L M S$ : Yeah. I guess it goes back to the fact that when I was growing u p I never thought of myself as having any sort of gender one way or the other. I mean, certainly I was aware that I was a girl, but if you've noticed my grandmother, she is in and out and she is seventy-four - when she was growing up she was a Model A mechanic, and even now, my uncle has a coin-operated laundry here and she fixes those machines and she carries heavy things. So she was there when I was growing up, and my father had three daughters, I was the oldest, and my father made no connections between the fact that we were daughters and not sons. He took me deer-hunting when I was seven years old, and then when I was a little girl I can remember when the crews would come to plaster the house, that they were women. The people who plaster the houses here traditionally have always been women, men do not plaster houses. So in all my surroundings I never ... I mean, I realized I was a girl, but I never saw that one's experiences or one's activities had to - either in my own family or just around me I never made the connection that because of one's sex one would be limited to certain kinds of experiences. I had a horse when I was eight years old, and as I got older I would go up north to the ranch - this is an area I write about a lot - and I would help them gather cattle and drive cattle.

PS: So because of your own experience and because of the manners and customs of the Laguna pueblos ...

$L M S$ : Right -

$P S$ : It simply was natural to you to have seen many aspects of what otherwise mostly men do ...

LMS : Right. And not to think that, not to feel that, in terms of the consciousness that I ... that there was something that one must exclusively be forced to stay within one consciousness.

$P S$ : How do you look upon black aesthetics, the fact that some blacks feel that only blacks should write for blacks, only blacks can judge anything written about the blacks. Is there any such feeling among Native American writers, and do you share it? 
LMS: I think it depends on whether the ... if the non-Indian writer wants to attempt to create a consciousness and pass off this consciousness as an Indian consciousness. I think there is an area where I would tend to say that that's on very uncertain, unsteady ground, that sooner or later in one's imagery and one's handling of that consciousness this non-Indian writer is going to get herself or himself into trouble. I think that the most important thing that any writer, any writer should remember in writing about any other person or group or culture is for the writer to remember where he or she has come from, and to always remember one's own experiences, and to be true ... or at least not to forget that the eyes that you've seen these people and these things with and the words that you use and the feelings you are putting into the work are yours, and they are coming from your origin, they are coming from your ancestors, and so that to always remember, then, always. keep that one thing straight, a perspective, then if one is honest one does not pretend to be the expert upon blacks, or the resident expert on upper middle class college professors or whatever, we keep this perspective. I think that's most important. Oliver LaFarge was a pioneer, he was the first, perhaps, to discover the difficulties when one attempts to take on the consciousness of a person worlds away from one's own culture. He would have done much better to have done a novel about the Eastern person, the white person who cared very much for the native American people, but who was Harvard educated, an ethnologist. Then he could have given us the different kinds of emotional things of the conflicts which he must have gone through, because I know that at that time, that the Navajos didn't always embrace him with open arms. But we don't get this, and as a writer I feel that that's the important thing. I think that's where the center lies.

PS: Yes. Unless you are a commercial writer.

LMS: Right. I guess, when I talk about writing I am always thinking about writing from the heart. And one must write from one's heart. And that seems to me so much more valuable for everybody, and as a native American people we could learn so much from an honest account from a person like LaFarge which we do not have, we could learn a lot about how he felt. We know how we feel, or the people they knew how they felt to have him around.

PS: You mentioned your father and your grandfather and all they have told you. Don't you feel that you have quite a store of material at the back of your head that you can call back at your 
leisure and in time bring to something, that you have a great donnée of material that you can use when it suits you?

$L S$ : Oh, right, precisely. I think of even my technical skill as a storyteller as a birthright. I recently went up to Laguna-Acoma highschool and spent all day with English classes. I said to them: "You know, they talk about different geographical areas and different groups of people having a resource, like they have uranium, they have gold, they have timber as a resource. This area is very interesting," I said, "doesn't it seem interesting to you that Simon Ortiz would come from Acomita, and I would be at Laguna, and then there's this one other guy, Robert Fernando, who one day just out of the blue sat down and wrote a fine short story." I said, "Don't you think there's something suspicious about this," I said, "because I do. Certain areas and certain people have another kind of 'resource'," and I said, "I think we all have it, we are very fortunate, we are lucky. Our greatest natural resource is stories and storytelling. We have an endless, continuing, ongoing supply of stories." And I said to them, "All of you have this and you should not forget it, and you shouldn't look upon Simon and myself as some kind of accident." I think it is something that many people here already possess, it is a part of the way of life, storytelling is. When you meet somebody around Laguna, you take a lot of time, you say, "Hello, how are you? Say, did you hear about what .happened the other night?" And then you take the time to start at the very beginning of what happened the other night. "My goodness, it started at noon the day before," and then you go into this very detailed telling, including the dialogue, of what so and so said to so and so. Well, this is something that the people have always done, this is something you hear from the time you are a little child. It's you talk about having a sense of the story and of recounting the story, just what elements need to be there and which don't. The people, all the people that I've ever known and continue to know have given this to me.

$P S$ : Yes. But still, you wouldn't say that just anyone here could write a story like "The Man to Send Rain Clouds" - you have gained something from what you have read, too, haven't you ?

$L S$ : Oh, right, I've ...

$P S$ : - some sense of technique, at least?

$L S$ : Yeah. I did a lot of reading when I was a child. There, again, I think, indirectly having developed this great appreciation for stories, I loved to read; and I loved the fact that you could go to 
books and inside of books were more stories, and stories from other places, and people around here have a tremendous appetite for stories and they don't even care where they came from. And so, yes, I did a lot of reading.

PS: What did you mostly read?

LMS : When I was thirteen or fourteen, I was very much interested in American authors, John Steinbeck and William Faulkner, and oh, Edgar Allan Poe. Possibly, again, what one reads is determined by the kinds of books that one finds. I can remember encountering Shakespeare in highschool and not liking Shakespeare very much, and then falling in love with him in college. Well, the first kinds of things I've read I can remember is Faulkner and Steinbeck and Poe. I don't know how much this most recent story I've written [Silko was here referring to "Escape Story"], the structure and all sorts of things turning in upon themselves, whether Borges, the Argentine, I'd love to read him, I became fascinated with him, maybe some of my most recent experiments and things were indirectly from him. Also Flannery $\mathrm{O}^{\circ}$ Connor - I use her all the time in my classes, and I tell my students, "Look, look what she's done." The students'd say, "Oh, she just writes about the same old area and countryside." "Well," I said, "Yes, that's true. I understand as a person, especially as she was ill in her later years she really didn't move around very much," and I said, "and that in a sense is one of-her greatest achievements, just to take these same sorts of things again and again and again to make these magnificent stories, you know."

PS: Yes. Do you use much invention or do you have so much inherited that you do not need to go much beyond that?

LMS: Well, you know, I never know how much I imagine and how much is actually what $I$ have heard and have forgotten and it comes back. Sometimes it can be rather frightening. Some other things I can't account for: One of the stories I wrote, the Tony story, the killing of the State policeman. OK, my father talked about it, and I heard other people talk about this incident that took place. I sat down and wrote this story, and in the story I took it from a very specific point of view, Tony's point of view, and I thought at the time that I was inventing this whole thing with the witch. Well, Larry Evers at the University of Arizona got very intrigued with the fact that Simon had written about the State police killing and $\mathbf{I}$ had, and so Larry started to do research into the old trial records and so forth, and he found that the man, the accused not 
$L M S$ : It's probably better to tell you what I don't like rather than what I do like as I like most all of the ... Also, there are so few of them. What I don't like: Well, again, I hesitate to go on about what I don't like. Let me just say that I see things, then, in poetry sometimes that seem to me a bit precious, or somehow it seems that the writers are bowing to expectations - that is, they feel that they are expected, because they are Native Americans, to write in a special way.

$P S:$ In subject matter and attitudes more than in technique?

$L M S$ : Well, even now in technique. I think it is probably the white writers more than any who have actually dictated what they think "Indian writing" should be. People like Rothenberg and of course Gary Snyder perfected the "white shamanism" movement. The attitude of the white shaman is that he knows more about Indians than the Indians know. It has happened with Indian graphic art and painting. The people who buy the paintings tell the Indian artist, "Don't do that, that's abstract - Indians ought to only do realistic sorts of paintings," and, "Oh, don't paint that, that's a picture of a drunken man passed out on the street of Gallup. That won't sell in our gallery, you know." In other words, white patrons have very much controlled and molded it. I can see it happening with the writing - publishers using Jerome Rothenberg's chants as a standard for judging poetry that Native Americans may write because Rothenberg appeals to the romanticized notion of what Native American literature is.

$P S$ : Do Native American writers as of today feel any pressure from publishers as to what to write, how to write?

$L M S$ : I don't think we are aware of any pressure yet. If there is going to be any pressure in the future, probably not a pressure to be angry as with the blacks, but perhaps more of this pressure to fall into some of these preconceived ... having people like, not Rothenberg specifically or someone like that, saying, "Why are you writing about 1952 GMC pick up trucks and Ripple wine?" you know, "Why aren't you writing about ... ." In other words, if there is any pressure it might be a Carlos Castaneda-Don Juan backlash, where Indian writers might be expected to always write about ethereal, mystical sorts of things when in fact those may not be the feelings they experienced at all. 
jail now, the reason he is in jail is because he did something while he was drinking, and the evil system has him in jail, the corrupt white system has him in jail and he is going to rot there." OK, I know a lot about the American justice system and that part is true. Once you're thrown in jail, unless you have lots of money for a fancy attorney, that's where you're going to stay. OK, that part is true. But what they miss is all of the personal subtleties and the unique experiences and aspects of this individual's life which have brought this person to this place in time. It is much more important to explore all of the possible depths and all of the possible details of a person's life and to range through time - back to a time before this person was born. This is how you begin to understand why these things happen. I feel it is more effective to write a story like "Lullaby" than to rant and, rave. I think it is more effective in reaching people. A.I.M. is simply another political group, and I find them too similar to other American political groups.

$P S$ : How do you feel about the Bicentennial - do you have feelings about it?

LS: Oh, I do, definitely, I have all kinds of things to say - I think it's one reason I'm very anxious to try to get the novel out during 1976. I just want to make sure that during this year when all of this sort of celebrating is going on, that Americans can be reminded that there are different ways to look at the past 200 years. I just want to make sure that beside all of the rhapsodizing about Paul Revere and George Washington and Benjamin Franklin that Americans are reminded that this great land, this powerful nation they are celebrating was established on stolen land. It was the resources, the metals, the minerals, it was the water, it was the coal, that enabled those people who came to America to build this nation. In this Bicentennial year we should remember, we should remember that it was on this stolen land that this country was settled and begun. In Anglo-Saxon law, in common law, when something is stolen, no matter how many times the stolen property changes hands, in common law, that piece of property still belongs to the original owner. It doesn't matter whether the people take the stolen article in good faith. The property remains stolen. As long as this fact is acknowledged, then I'll be satisfied, and they can celebrate all they have done with this stolen land and the stolen resources and they can pat themselves on the back for the achievement.

$P S$ : What Native American writers do you like? 
$L M S$ : It's probably better to tell you what I don't like rather than what I do like as I like most all of the ... Also, there are so few of them. What I don't like: Well, again, I hesitate to go on about what I don't like. Let me just say that I see things, then, in poetry sometimes that seem to me a bit precious, or somehow it seems that the writers are bowing to expectations - that is, they feel that they are expected, because they are Native Americans, to write in a special way.

$P S$ : In subject matter and attitudes more than in technique?

$L M S$ : Well, even now in technique. I think it is probably the white writers more than any who have actually dictated what they think "Indian writing" should be. People like Rothenberg and of course Gary Snyder perfected the "white shamanism" movement. The attitude of the white shaman is that he knows more about Indians than the Indians know. It has happened with Indian graphic art and painting. The people who buy the paintings tell the Indian artist, "Don't do that, that's abstract - Indians ought to only do realistic sorts of paintings," and, "Oh, don't paint that, that's a picture of a drunken man passed out on the street of Gallup. That won't sell in our gallery, you know." In other words, white patrons have very much controlled and molded it. I can see it happening with the writing - publishers using Jerome Rothenberg's chants as a standard for judging poetry that Native Americans may write because Rothenberg appeals to the romanticized notion of what Native American literature is.

PS : Do Native American writers as of today feel any pressure from publishers as to what to write, how to write?

$L M S$ : I don't think we are aware of any pressure yet. If there is going to be any pressure in the future, probably not a pressure to be angry as with the blacks, but perhaps more of this pressure to fall into some of these preconceived ... having people like, not Rothenberg specifically or someone like that, saying, "Why are you writing about 1952 GMC pick up trucks and Ripple wine?" you know, "Why aren't you writing about ... ." In other words, if there is any pressure it might be a Carlos Castaneda-Don Juan backlash, where Indian writers might be expected to always write about ethereal, mystical sorts of things when in fact those may not be the feelings they experienced at all. 
: Oslo, September.12, 1978

S: What time is "The Man to Send Rain Clouds" set - is it very cent?

MS: Yes, it is very recent. It's perhaps in the middle 1960s. It's quite recent story. The reason I am so sure of this is because it's ased upon something vaguely similar that actually happened. S: Yes, I believe you had some special inspiration for this story? $M S$ : Well, it's like most of the inspirations for my stories. One eekend I drove to Laguna from Albuquerque, as I often did to sit home while I was in undergraduate school. When I would get - Laguna I would hear all the news, all the stories of things that id been happening that week, that month, since I had had my st visit. And one particular weekend I went home, and they said, Did you hear that old man Sorsino died?" and I said, "Oh, I no, I didn't know that," and they said, "Yes, they found him it at sheep pen. He'd been dead for a day or so, and the sheep ere scattered all over by the time they got there." And then my randmother said, "And the Catholic priest was very angry," and said, "What about?" "Well," she said, "they buried the old man ithout telling the priest. They just did the traditional ceremonies id had a traditional funeral and they didn't tell the priest, and e priest was very upset." And I said, "Oh. Well." And that was $\mathrm{L}$, and I didn't think more of it because visits, if you know Laguna id the way the people tell stories, that was only one of many ings $\mathbf{I}$ heard that weekend. And I went back to Albuquerque iere I was attending the University of New Mexico, and that mester I was taking a creative writing class, and one of my ofessors, the following week told us we had to write a short story. ad I thought, "Well, I'll just write about poor old man Sorsino." - I wrote about him, imagining how it must have been when ey found him, and also I tried to imagine the Catholic priest and ; feelings. So that's how this story came.

$\therefore$ In Ceremony, you make a very interesting combination of the st that your pueblo or the pueblo close to it, Acoma, is very old, age goes in America, together with the fact that close to Laguna $\mathrm{u}$ have had the various uranium and atomic installations.

US : That's something that for a long time I suppose I didn't really preciate, the irony. The Pueblo people have always concentrated on making things grow, and appreciating things that are alive $\mathrm{d}$ natural, because life is so precious in the desert. The irony is 
that so close to us, in Los Alamos, New Mexico, scientists began the scientific and technological activity which created the potential end to our whole planet, the whole human race. The first atomic bomb was exploded in New Mexico, very close by us. To me it is very striking that this happened so close to the Pueblo people, but I suppose it is just one of those accidents of history.

$P S$ : Have you by any chance read Frank Waters' book where he makes that connection between the old and the new culture?

$L M S$ : No, I never have. I think it was easier for me to make the connection, because as a child, people still talked about that day when the bomb was exploded. It was done early in the morning before sunrise, and people at Laguna, some of the old people that got up before sunrise, as was their practice, remembered that the whole sky in the southeast lit up, and it was a remarkable sort of thing and people remember it. So I think that's where I made the connection.

$P S$ : I understand that when you came to visit us now, Norway wasn't entirely unknown to you.

LMS: When I was just a schoolgirl, I had a teacher in the fifth grade, and she was of Scandinavian background. Very early, she read us some of these Scandinavian or Norse tales, and so I learned about Tor and Odin and Loke, and all the wonderful stories of Vulcan, and she read those stories to us, and as a little girl, coming from Laguna, I love stories, we have a great appreciation for stories. And I thought these stories were quite wonderful, and so after she read to us - she only read us a few - I asked her where I could get the book, because it was a large book, and I read the whole book, and - well, tonight we were talking about this - the most sad thing for me is that at the end of this book of Norse tales is a chapter which in the book I read was called "Twilight of the Gods," and I had to read that all these gods would die and that this time ended, and it was very upsetting. It was tragic for me, because at Laguna, we believe that those times did not truly end, but that things only change, and so I was quite horrified to read that for some other people in this other place, that there was this twilight of the gods. So I, years ago, already loved these characteristic deities from the Norse country.

PS: Wouldn't you say, coming from Laguna, from these old Pueblos, that story-telling is not only a way of life, it is also as a sort of continuation of past life in that community, and therefore important to you also for that reason? 
$L M S$ : Oh yes, very much so. In fact, one of the older women - we called her Aunt Susy - who told me a lot of the stories, and who in some sense trained me, if that's what you want to call it, helped me to love the stories and learn them - she always said when she told the stories that there was an old custom, long ago, where the storyteller would say to one of the persons in the room, "Go open the door, go open the door so that they can come in," and it was as if "they," being ancestors, can come in and give us their gifts which are these stories, and that through the stories, somehow, even though people may be dead or gone or time is gone a long way in the past, that through the storytelling there was a belief that it all came back very immediately, that it came right back in the room with you. And so the storytelling in that sense was an act of ... so that there wasn't anything lost, nothing was dead, nobody was gone, that in the stories everything was held together, regardless of time. And so, when I read the story about "The Twilight of the Gods" it was very upsetting, you see, for a person who was taught to believe that "No, these things go on and on and on." As long as we tell the stories, you know, then these things continue. The stories will only - these things will only die if we neglect to tell the stories. So I am still telling the stories.

$P S$ : You also told us today an instance of the healing effect that stories can have. You mentioned a veteran who forgot to put on the brake when he parked his brand new car so that it rolled into a ravine and was wrecked, and who was then comforted by his fellow Pueblos who told him of similar accidents ...

$L M S$ : Yes, the stories are very important in many different ways. There are the usual ways that people find stories important in terms of history because, of course, the term in English is a combination of the word "story" - "his" "story," but at Laguna, the stories also serve to help the individual feel constantly a part of the group so that a person will never feel remote or lost no matter the time or situation. The way this functions is that, if something happens to you, as soon as something terrible happens to you, people come to you - and first of all, things are not kept private, I think that's important - so as soon as something terrible happens, people hear about it, and people come to you, whatever it might be, and the first thing people begin to do is they begin to tell you stories about other people and this has a very soothing effect - they don't talk about what just happened to you, but they'll say, "Well, now, that happened to my uncle, that happened to my uncle many 
years ago, the same sort of thing." And then, they will either tell you stories about the same sort of tragic thing, or, if this tragic thing that just happened to you took place in a certain geographical location, they may not tell you a story about a similar incident, but they'll say, "Well, bad things always happen at that place," and then they'll begin to tell about some kind of other terrible thing that happened at that place. And so people will come to you with all these other stories, and of course, the obvious immediate effect is they are taking your attention away from yourself, because you are hearing about other people and other incidents. It helps put things into perspective. We human beings have a tendency to think that we are the only ones that have ever experienced loss or sorrow. We're so self-centered. With the stories you begin to realize that what has just happened to you has happened before to different people. People will recount incidents worse than your own, so that by the time they get finished telling you all these other stories you realize you are not alone. You realize there arc many people who have had the same thing happen to them. The best part is that you realize that for many years, in the future, even after you're gone, your story is joining all these other stories, and some day when something terrible happens to somebody else, they'll mention your story, too. So it is not as if it just happencd to you or that there is nothing to be gained from your tragedy or loss. You have this sense that there's this ongoing story and your story has become part of it.

PS: You can still be of use to later generations ...

$L M S$ : Right. Through the story.

$P S$ : You mentioned earlier today the feeling of self-worth. Do you feel that the so-called ethnic revival of the last 10 or 15 years has meant the same to the Indians as it has, for example, to the American blacks?

EMS: Yes, I think it has meant a lot to the people, both for the people who had their feeling of self-worth somehow undermined, or wounded, by schools, and also, I think, it has helped the older people who always believed - who always believed in the worth and the value of the Pueblo culture. I think it made them feel free to talk about the culture. The older people always felt that the Pueblo ways were as valid as the non-Indian ways which their children and grandchildren were being forced to learn, but they were afraid to say so, or they were afraid that maybe they would hinder their children or grandchildren if they tried to encourage 
them toward Pueblo language or toward Pueblo ways. This ethnic revival has freed them to teach things about the culture, the old stories, and things about the language which they might not have done so freely. They might have died without saying some of the things which are now being said. And in the religious ways, this revival has encouraged some of the older priests and religious persons to ask the younger people to come with them. And younger people, because of this revival, are not afraid or not ashamed. They want to come. So I think it has come in time for us, for the Pueblo people.

$P S$ : Not too late, you'd say, but just in time ...

LSM: Not too late, but just in time, just barely, which isn't to say that it's all going to be easy or that it's all going to be just perfect, or that no real damage was done by all these hundreds of years. I only wish that for some other Native American people it might have come sooner, because I suspect that perhaps for some groups, certainly for some individuals, it might be too late, but we make the best of what we can.

$P S$ : Has there been a development among the Indians, as with the blacks after Roots, to try to find out who were your grandparents, and so on?

LMS: A kind of research such as Alex Haley had to undertake isn't necessary, thank heavens, at Laguna. One of the things which is passed on from generation to generation among all the stories, that are told, are stories about grandparents, great-grandparents, their great-grandparents and their great-grandparents, and on and on and on. And the people have a great deal of patience with the naming of these ancestors, where they came from and which clan they were from and so forth. And so this was one of the things that's just second nature to the people, keeping track of these things. And of course, it is very easy because we have been living in this same area for so long. It's very easy even if some of your ancestors have gone from Paguate village to Laguna, or from Laguna to Seama - we are only talking about 6 miles at most. If someone were to die suddenly and not pass on a certain amount of information to you, it's still possible to get those things. Again that goes back to everyone knowing so much about everyone else. It's as if each person were a source, and so it's all right here.

PS: You have named your novel Ceremony. What does the word "ceremony" stand for for you? 
$L M S$ : Well, for me, it's the term we use when we refer to certain religious activities. I first heard it connected with the activities which the Navajos participate in in order to cure, healing, medicinal sorts of activities. And the Navajos would say in English, "Old so and so has been sick, so they're giving him a ceremony," or ','They're having a ceremony for him." And so that's where I first heard the term, and that's how it will be used in English. Basically it refers to those kinds of activities. It can also refer to other sorts of activities, not necessarily healing ceremonies, but celebrations or giving thanks, those sorts of ceremonies.

$P S$ : Could you say a little about how you feel Tayo is cured, how the ceremonies worked for him?

$L M S$ : Well, it's fairly complex, I think, in the novel. He is first visited by Ku'oosh, and this old medicine man from Laguna is familiar with the scalp ceremony which was a purification ceremony which was done for warriors, or anybody that might have killed another human being in battle, because of course killing another human being was not taken lightly, it was a very devastating sort of thing, a tremendous thing -

$P S:$ And at the same time American Indians joined up to take part in the war -

$L M S$ : Right. The people at home were very, what you would say, patriotic.

$P S$ : Patriotic Americans -

$L M S$ : Patriotic Americans. They were some of the first people to join up. So very many of the Pueblo men went, joined up and went to the second World War. And also in later wars, the Korean war, the Vietnam war, many American Indians went. So, in the beginning, then, of the novel, certain Laguna rituals have been tried, to no avail, with this particular character. And he is sent, then, to this Navajo medicine man, who is a little bit notorious. The other Navajos don't agree with what he does.

$P S$ : A somewhat questionable character -

$L M S$ : Yes, a questionable character, questionable in terms of the purity of his ritual. Some of the other Navajos would say that he's taking liberties with the ritual, they didn't trust him. But the people in Tayo's family had heard that this medicine man was particularly successful with individual suffering from the effects of things connected with Anglo-Saxon culture. Alcoholism, and those sorts of things. They were willing to try, and so Tayo goes to this medicine man. But truly, the thing that heals Tayo is not only that particular 
ceremony which involves the sandpainting, it is the greater ceremony which helps Tayo to get well. Tayo's healing is connected to the faith which this old medicine man had, a faith which went back to things far in the past, the belief that it's human beings, not particular tribes, not particular races or cultures, which will determine whether the human race survives. But all people have to constantly be working, otherwise we will manage to destroy ourselves -

$P S$ : Working at being sane -

$L M S$ : Yeah, working at being sane, and taking care of each other. And so, it's because this medicine man reminds Tayo of humanity, of something larger than just the individual and the individual community. He puts Tayo in touch with this larger feeling.

$P S$ : That he is part of humanity -

$L M S$ : Right, that he is part of humanity, and feeling a part again, not just of the tribe, but of humanity, is a very healing sort of thing, and that as human beings we need that. When they say that the human being is a social animal, that's not to be taken lightly, it's almost a spiritual sort of thing. And so once lie's joined again, or reminded that he's always been joined - I think that's the important point, that he's always been joined together - once he is reminded of this and can find it again within himself, then the other things he does are acts which reiterate this closeness. They're important acts, but they only help to reiterate this -

$P S$ : This closeness to the integrity he has in himself and has always had in himself -

$L M S$ : So nothing happens, nothing is given or put into him that hasn't always been there. The only thing that changes is his awareness, his perception of himself in relation to the rest of the world. $P S$ : And wouldn't you also say that it's an important part of the healing process, and thus of your book, to see that evil is everywhere, not just in the Anglos, but also in the Pueblos, and for that matter, in Tayo himself, that it is - again back to your word humanity - it's common humanity?

LMS: Right. That's terribly important, I think, because it's especially easy to blame oneself and say, "It's only me, this evil, this bad is within me." That's too easy, too simple. And so is the opposite, which is just to blame others - to say, "It's white people," or, "It's those people, it's not me," and thereby withdraw in the same way. Either way isolates us from other human beings. If we say "It's all just me," then we're isolated. If we're saying "It's 
everybody else but me," it's the same sort of isolation. Radical Indian politicians like to say, "Well, it's all the white people's fault, you know, we didn't do any of this." That's such a simplistic view, because from the very beginning, the betrayals of our people occurred through deeply complicated convergences of intentions and world views. And there were persons, full-blood Indians, who cooperated with the enemy, or who cooperated with the invaders, and there were mixed blood or "half-breed" people who did that's human nature.

$P S$ : As you had with the blacks in Africa during slave trading times -

LMS: Right. Sure. It's something about us as humans, not about us as any particular race or group. It's nice to think that none of our people have the capability of doing anything treasonous. But unfortunately, as long as we're all human beings, there are certain human traits which turn up, and so it is important that Tayo discovers that the Destroyers and the destructive impulse don't reside with a single group or a single race, and that to manipulate people into war or other conflicts again is a human trait, it is a worldwide thing. It's not just one group of people, that's too simple. $P S$ : Yes, this was just what I would like to end on, this note that your book is not only about some American Indian people, but very much about Everyman who could have been in somewhat the same situation. Thank you very much.

$L M S$ : Thank you. 